\title{
Improvement of Interest And Learning Results of Science with Problem Based Learning Model in SD Negeri Keteleng 02
}

\author{
Fera Setiyadi \\ SD Negeri Keteleng 02 \\ ferasetiadi@gmail.com
}

\section{Article History}

accepted $14 / 11 / 2020$

approved 21/11/2020

published 26/11/2020

\begin{abstract}
The purpose of this study was to increase the interest and learning outcomes of students in the science muple in grade IV elementary schools with the Problem Based Learning (PBM) learning model. The research conducted was a Classroom Action Research (CAR) in three cycles, with each cycle consisting of one meeting. The stages of each cycle are planning, implementing, observing and reflecting. Each meeting is carried out a pre test and post test to determine the progress of students. In cycle I students who completed after carrying out the post test were 74\%. In cycle II participants students who complete after carrying out the post test are $100 \%$. These results indicate that the Problem Based Learning (PBM) learning model can improve student learning outcomes, especially Class IV science muple at SDN Keteleng 02.
\end{abstract}

Keywords: Learning outcomes, problem based learning, science

\section{Abstrak}

Tujuan dari penelitian ini adalah untuk meningkatkan minat dan hasil belajar peserta didik pada mupel IPA di sekolah dasar kelas IV dengan model pembelajaran Problem Based Learning (PBL). Penelitian yang dilakukan adalah Penelitian Tindakan Kelas (PTK) sebanyak tiga siklus, dengan setiap siklusnya terdiri dari satu pertemuan. Tahapan setiap siklusnya adalah perencanaan, pelaksanaan, observasi dan refleksi. Setiap pertemuan dilakukan pre test dan post test untuk mengetahui perkembangan peserta didik. Pada siklus I peserta didik yang tuntas setelah melaksanakan post test sebesar $74 \%$. Pada siklus II peserta didik yang tuntas setelah melaksanakan post test sebesar $100 \%$. Hasil ini menunjukan bahwa model pembelajaran Problem Based Learning (PBM) dapat meningkatkan hasil belajar peserta didik khususnya mupel IPA Kelas IV di SDN Keteleng 02

Kata kunci: Hasil belajar, problem based learning, IPA

Social, Humanities, and Education Studies (SHEs): Conference Series https://jurnal.uns.ac.id/shes 


\section{PENDAHULUAN}

Sesuai dengan Permendikbud nomor 67 tahun 2013 tentang kurikulum Sekolah Dasar, Kurikulum 2013 bertujuan untuk mempersiapkan manusia Indonesia agar memiliki kemampuan hidup sebagai pribadi dan warga negara yang beriman, produktif, kreatif, inovatif, dan afektif serta mampu berkontribusi pada kehidupan bermasyarakat, berbangsa, bernegara, dan peradaban dunia. Kurikulum 2013 dikembangkan dengan landasan filosofis yang memberikan dasar bagi pengembangan seluruh potensi peserta didik menjadi manusia Indonesia berkualitas yang tercantum dalam tujuan pendidikan nasional. Kurikulum 2013 dikembangkan atas teori "pendidikan berdasarkan standar" (standard-based education), dan teori kurikulum berbasis kompetensi (competency-based curriculum). Pendidikan berdasarkan standar menetapkan adanya standar nasional sebagai kualitas minimal warganegara yang dirinci menjadi standar isi, standar proses, standar kompetensi lulusan, standar pendidik dan tenaga kependidikan, standar sarana dan prasarana, standar pengelolaan, standar pembiayaan, dan standar penilaian pendidikan. Kurikulum berbasis kompetensi dirancang untuk memberikan pengalaman belajar seluas-luasnya bagi peserta didik dalam mengembangkan kemampuan untuk bersikap, berpengetahuan, berketerampilan, dan bertindak.

Dalam pelaksanaan pembelajaran muatan IPA di kelas IV semester I SD Negeri Keteleng 02 Kecamatan Blado Kabupaten Batang masih banyak kendala yang muncul. Kendala tersebut antara lain Siswa kurang memperhatikan guru ketika proses belajar mengajar, siswa selalu beranggapan bahwa mata pelajaran IPA rumit. Minat siswa terhadap mata pelajaran IPA sangat rendah, siswa hanya mengerjakan latihan soal jika disuruh oleh guru, penggunaan metode ceramah sangat dominan, penggunaan peraga belum menarik bagi siswa. Hal tersebut secara tidak langsung telah mempengaruhi prestasi siswa dari tes formatif materi kelas IV SD Negeri Keteleng 02 Kecamatan Blado Kabupaten Batang peneliti mengalami kegagalan karena dari jumlah 7 siswa hanya 3 siswa (36\%) yang mendapat nilai diatas 75,00 (tuntas) sedangkan 4 siswa $(64,00 \%)$ mendapat nilai dibawah KKM

Bertolak dari uraian di atas, maka sebagai jalan keluar peneliti berupaya meningkatkan pembelajaran muatan IPA, karena hasil belajar muatan IPA yang rendah merupakan suatu permasalahan yang harus segera diatasi. Untuk mengatasi masalah tersebut guru harus menciptakan suasana pembelajaran yang menyenangkan. Kegiatan menyenangkan dapat tercipta apabila guru menggunakan metode yang bervariasi dan media yang relevan serta menggunakan pendekatan dan model pembelajaran yang tepat. Dengan demikian siswa akan tertarik mempelajari IPA dan pembelajaran menjadi lebih bermakna dan tujuan pembelajaran akan tercapai. Dan diharapkan untuk hasil belajar muataan IPA pada materi sifat - sifat cahaya dari 7 siswa,80 \% siswa mendapat nilai diatas 75 dan mengalami ketuntasan hasil belajar $100 \%$.

\section{METODE}

Penelitian ini dilaksanakan dengan melaksanakan perencanaan yang telah dibuat sebelumnya yakni melaksanakan pembelajaran dengan menggunakan model Problem Based Learning.

Pelaksanaan tindakan penelitian ini direncanakan dalam tiga siklus. Siklus pertama dilaksanakan pembelajaran dengan model Problem Based Learning. Siklus kedua dilaksanakan untuk memperbaiki segala sesuatu yang belum baik pada siklus satu dan Siklus Ketiga dilaksanakan untuk memperbaiki segala sesuatau yang belum baik pada siklus dua.

Baik pre test maupun post test. Observasi dalam penelitian ini berisi catatan yang menggambarkan bagaimana aktifitas, minat dan hasil belajar siswa dalam pembelajaran materi sifat-sifat cahaya dan keterkaitanya dengan indera penglihatan 
pada siswa kelas IV SD Negeri Keteleng 02 muatan IPA sebelum menggunakan model Problem Based Learning dan sesudah menggunakan model Problem Based Learning.

\section{HASIL DAN PEMBAHASAN}

Pada siklus I pembelajaran dilaksanakan selama satu pertemuan, setiap pertemuan diadakan pre test dan post test. Untuk mengetahui perkembangan peserta didik selama pembelajaran. Siklus I membahas materi sifat - sifat cahaya dan keterkaitanya dengan indera penglihatan. Pembelajaran dengan model PBL dilaksanakan dengan 5 langkah. secara berurutan mulai dari Menelaah materi sifatsifat cahaya dan keterkaitanya dengan indera penglihatan.muatan IPA kelas IV semester 1 yang akan dilakukan tindakan penelitian dengan menelaah indikatorindikator pelajaran. Menyiapkan alat evaluasi yang berupa pre test dan post test, serta lembar kerja siswa, merancang proyek, menyusun jadwal, memantau proses proyek, penilaian hasil dan evaluasi pengalaman. Proyek yang dibuat peserta didik adalah melakukan percobaan pemantulan cahaya dengan menggunakan cermin dan senter. Berikut ini adalah hasil belajar peserta didik pada siklus I yang bisa dilihat pada tabel berikut.

Tabel 1. Hasil Belajar Peserta Didik Siklus I

\begin{tabular}{ccccccccc}
\hline & \multicolumn{3}{c}{ Pre Test } & \multicolumn{4}{c}{ Post test } \\
Siklus I & $\begin{array}{c}\text { Presdik } \\
\text { Tuntas }\end{array}$ & \multicolumn{2}{c}{ Presdik } & \multicolumn{2}{c}{ Presdik } & \multicolumn{2}{c}{ Presdik } \\
& Jml & $\%$ & Jml & $\%$ & Jml & $\%$ & Jml & $\%$ \\
\hline 1 Pertemuan & 2 & 28,6 & 5 & 71.5 & 3 & 42.9 & 4 & 57,2 \\
\hline
\end{tabular}

Berdasarkan tabel di atas maka terjadi peningkatan antara pre test dan post test. Setiap individu peserta didik sudah mengalami peningkatan hasil belajarnya. Ketuntasan klasikal juga mengalami peningkatan, pada pre test hanya terdapat 2 anak yang sudah tuntas, tetapi pada post test bertambah menjadi 3 anak yang sudah tuntas dengan Kriteria Ketuntasan Minimal (KKM) sebesar 75. Dari 7 siswa hanya 4 siswa $(57,2 \%)$ yang mendapat nilai di atas KKM, sedangkan 3 siswa $(42,9 \%)$ nilainya masih di bawah KKM

Berdasarkan refleksi pada siklus I maka diputuskan untuk melanjutkan ke siklus II dikarenakan belum mencapai ketuntasan klasikal yang diharapkan. Siklus II membahas membahas materi sifat - sifat cahaya dan keterkaitanya dengan indera penglihatan. Pembelajaran dengan model PBL dilaksanakan dengan 5 langkah. secara berurutan mulai dari Menelaah materi sifat-sifat cahaya dan keterkaitanya dengan indera penglihatan.muatan IPA kelas IV semester 1 yang akan dilakukan tindakan penelitian dengan menelaah indikator-indikator pelajaran. Menyiapkan alat evaluasi yang berupa pre test dan post test, serta lembar kerja siswa, merancang proyek, menyusun jadwal, memantau proses proyek, penilaian hasil dan evaluasi pengalaman. Proyek yang dibuat peserta didik adalah melakukan percobaan pemantulan cahaya dengan menggunakan cermin dan senter. Berikut ini adalah hasil belajar peserta didik pada siklus II yang bisa dilihat pada tabel berikut. 
SHEs: Conference Series 3 (3) (2020) $1315-1319$

Tabel 2. Hasil Belajar Peserta Didik Siklus II

\begin{tabular}{|c|c|c|c|c|c|c|c|c|}
\hline \multirow{3}{*}{ Siklus II } & \multicolumn{4}{|c|}{ Pre Test } & \multicolumn{4}{|c|}{ Post test } \\
\hline & \multicolumn{2}{|c|}{$\begin{array}{l}\text { Presdik } \\
\text { Tuntas }\end{array}$} & \multicolumn{2}{|c|}{$\begin{array}{c}\text { Presdik } \\
\text { Belum Tuntas }\end{array}$} & \multicolumn{2}{|c|}{$\begin{array}{l}\text { Presdik } \\
\text { Tuntas }\end{array}$} & \multicolumn{2}{|c|}{$\begin{array}{c}\text { Presdik } \\
\text { Belum Tuntas }\end{array}$} \\
\hline & $\mathrm{Jml}$ & $\%$ & $\mathrm{Jml}$ & $\%$ & $\mathrm{Jml}$ & $\%$ & $\mathrm{Jml}$ & $\%$ \\
\hline 1 Pertemuan & 4 & 57,2 & 3 & 42,9 & 5 & 71,5 & 2 & 28,6 \\
\hline
\end{tabular}

Berdasarkan tabel di atas maka terjadi peningkatan antara pre test dan post test Setiap individu peserta didik sudah mengalami peningkatan hasil belajarnya. Ketuntasan klasikal juga mengalami peningkatan, pada pre test hanya terdapat 4 anak yang sudah tuntas, tetapi pada post test bertambah menjadi 5 anak yang sudah tuntas dengan Kriteria Ketuntasan Minimal (KKM) sebesar 75. Dari 7 siswa hanya 4 siswa $(57,2 \%)$ yang mendapat nilai di atas KKM, sedangkan 3 siswa (42,9\%) nilainya masih di bawah KKM

Setelah melakukan refleksi pada siklus II, maka diputuskan untuk melanjutkan pada siklus III. Hal ini dilakukan agar mengetahui sejauh mana penerapan pembelajaran PBL tidak hanya meningkatkan tetapi juga mempertahankan hasil belajar peserta didik. Pada siklus III materi yang diajarkan adalah sifat - sifat cahaya, Hasil belajar peserta didik dapat dilihat pada tabel berikut.

Tabel 3. Hasil Belajar Peserta Didik Siklus III

\begin{tabular}{|c|c|c|c|c|c|c|c|c|}
\hline \multirow{3}{*}{ Siklus III } & \multicolumn{4}{|c|}{ Pre Test } & \multicolumn{4}{|c|}{ Post test } \\
\hline & \multicolumn{2}{|c|}{$\begin{array}{l}\text { Presdik } \\
\text { Tuntas }\end{array}$} & \multicolumn{2}{|c|}{$\begin{array}{c}\text { Presdik } \\
\text { Belum Tuntas }\end{array}$} & \multicolumn{2}{|c|}{$\begin{array}{l}\text { Presdik } \\
\text { Tuntas }\end{array}$} & \multicolumn{2}{|c|}{$\begin{array}{c}\text { Presdik } \\
\text { Belum Tuntas }\end{array}$} \\
\hline & $\mathrm{Jml}$ & $\%$ & $\mathrm{Jml}$ & $\%$ & $\mathrm{Jml}$ & $\%$ & $\mathrm{Jml}$ & $\%$ \\
\hline 1 Pertemuan & 6 & 90 & 1 & 35 & 7 & 100 & 0 & 0 \\
\hline
\end{tabular}

Ketuntasan klasikal mengalami peningkatan, pada pre test terdapat 6 anak yang sudah tuntas, tetapi pada post test bertambah menjadi 7 anak yang sudah tuntas dengan Kriteria Ketuntasan Minimal (KKM) sebesar 75.

Dari tiga siklus yang sudah dilaksanakan selama 3 pertemuan dapat dipastikan bahwa model pembelajaran PBL dapat meningkatkan hasil dan minat belajar peserta didik pada mupel IPA Kelas IV di SD Negeri Keteleng 02. Hal ini sesuai dengan konsep atau teori yang diungkap oleh menurut Kamdi (2007:77) berpendapat bahwa:

Model Problem Based Learning diartikan sebagai sebuah model pembelajaran yang didalamnya melibatkan siswa untuk berusaha memecahkan masalah dengan melalui beberapa tahap metode ilmiah sehingga siswa diharapkan mampu mempelajari pengetahuan yang berkaitan dengan masalah tersebut dan sekaligus siswa diharapkan akan memilki keterampilan dalam memecahkan masala Memang benar adanya dengan model PBL peserta didik akan membangun sendiri pengetahuannya. Karena Problem-Based Learning adalah pembelajaran yang menggunakan masalah nyata (autentik) yang tidak terstruktur (ill-structured) dan bersifat terbuka sebagai konteks bagi peserta didik untuk mengembangkan keterampilan menyelesaikan masalah dan berpikir kritis serta sekaligus membangun pengetahuan baru. Berbeda dengan pembelajaran konvensional yang menjadikan masalah nyata sebagai penerapan konsep, PBM menjadikan masalah nyata sebagai pemicu bagi proses belajar peserta 
didik sebelum mereka mengetahui konsep formal. Peserta didik secara kritis mengidentifikasi informasi dan strategi yang relevan serta melakukan penyelidikan untuk menyelesaikan masalah tersebut. Dengan menyelesaikan masalah tersebut peserta didik memperoleh atau membangun pengetahuan tertentu dan sekaligus mengembangkan kemampuan berpikir kritis dan keterampilan menyelesaikan masalah. Mungkin, pengetahuan yang diperoleh peserta didik tersebut masih bersifat informal. Namun, melalui proses diskusi, pengetahuan tersebut dapat dikonsolidasikan sehingga menjadi pengetahuan formal yang terjalin dengan pengetahuan-pengetahuan yang telah dimiliki peserta didik.

\section{SIMPULAN}

Proses pembelajaran dengan menerapkan model pembelajaran Problem Based Learning dalam pembelajaran materi sifat-sifat cahaya muatan IPA pada siswa kelas IV SD Negeri Keteleng 02 semester 1 tahun pembelajaran 2020/2021 dilaksanakan secara bertahap dalam 3 kali pertemuan. Terjadi peningkatan yang signifikan terhadap minat pembelajaran materi sifat sifat cahaya pada mupel IPA hal tersebut terbukti pada terus meningkatanya prosentase nilai pada setiap siklus

\section{DAFTAR PUSTAKA}

Aprilia. (2009). Ilmu Pengetahuan Alam 4 : Untuk Sd Dan Mi Kelas 4. - Jakarta: Pusat, Perbukuan, Departemen Pendidikan Nasional.

Aqib, Z. (2006). Penelitian Tindakan Kelas.Bandung : Yrama Widia.

Ariani, Windy. (2006). Pengembangan Model Pembelajaran Inkuiri Untuk Meningkatkan Hasil Belajar Siswa SD Pada Pembelajaran Sains. Skripsi Sarjana Jurusan Fisika FPMIPA UPI: Tidak diterbitkan.

Choiril Azmiyawati, Wigati Hadi Omegawati, dan Roma Kusumawati. (2008). IPA Salingtemas: untuk SD/MI Kelas IV. Jakarta: pusat Pembukuan, Departemen Pendidikan Nasional.

Iskandar, Srini M. (2007). Pendidkan Ilmu Pengetahuan IPA. Bandung: Dekdikbud.

Kemmis, Taggart. (1998). Model Alur PTK. Tersedia: http://tradednow.info/tags/penelitian-tindakan-kelas-model-kemmis-dan-mc-.[10 Oktober 2013].

Sularmi, M.D Wijayanti. (2009). Pendidkan IImu Pengetahuan IPA SD/MI Kelas IV/llustrasi, Tiras.-Jakarta: Pusat Pembukuan, Departeman Pendidikan Nasional.

Supratman Ocep. (2011). Implementasi Metode Eksperimen Dalam Upaya Meningkatkan Hasil Belajar Siswa Pada Konsep Sifat Cahaya Dalam Pembelajaran Ipa Di Sekolah Dasar Kelas IV Sdn Simpen IV Kabupaten Garut. Skripsi Sarjana PGSD Jurusan Pedagogik FIP UPI: Tidak diterbitkan.

Sya'bani Fauziah Wulan. (2008). Upaya Meningkatkan Keterampilan Siswa Dalam Menerapkan Konsep Pada Topik Sifat Benda Melalui Model Pembelajaran Inkuiri. Skripsi Sarjana PGSD Jurusan Pedagogik FIP UPI: Tidak diterbitkan.

S. Rositawaty, Aris Muharam. (2008). Senang Belajar IImu Pemgetahuan Alam 4: Untuk Kls IV. Jakarta: Pusat Pembukuan, Departemen Pendidikan Nasional. 